This item was submitted to Loughborough's Research Repository by the author.

Items in Figshare are protected by copyright, with all rights reserved, unless otherwise indicated.

\title{
Exploring knowledge management perspectives in smart city research: A review and future research agenda
}

PLEASE CITE THE PUBLISHED VERSION

https://doi.org/10.1016/j.ijinfomgt.2019.07.015

\section{PUBLISHER}

Elsevier BV

VERSION

AM (Accepted Manuscript)

\section{PUBLISHER STATEMENT}

This paper was accepted for publication in the journal International Journal of Information Management and the definitive published version is available at https://doi.org/10.1016/j.ijinfomgt.2019.07.015

\section{LICENCE}

CC BY-NC-ND 4.0

\section{REPOSITORY RECORD}

Israilidis, John, Kayode Odusanya, and Muhammad Usman Mazhar. 2019. "Exploring Knowledge Management Perspectives in Smart City Research: A Review and Future Research Agenda”. Loughborough University. https://hdl.handle.net/2134/9802169.v1. 


\section{Article Title Page}

Title: Exploring Knowledge Management perspectives in Smart City Research: A review and future research agenda

\section{Author Details:}

Author 1 Name:

Dr John Israilidis

Department:

Nottingham Business School

Institution:

Nottingham Trent University

Town/City: Nottingham

Country:

UK

Author 2 Name: $\quad$ Dr Kayode Odusanya

Department:

Nottingham Business School

Institution:

Nottingham Trent University

Town/City:

Nottingham

Country:

UK

Author 3 Name: $\quad$ Dr Muhammad Usman Mazhar

Department: Nottingham Business School

Institution: Nottingham Trent University

Town/City: Nottingham

Country: UK

Corresponding author: Dr Kayode Odusanya

Corresponding Author's Email: kayode.odusanya@,ntu.ac.uk

\section{Biographical Details:}

John Israilidis, $\mathrm{PhD}$, is a Senior Lecturer at Nottingham Business School, Nottingham Trent University. His current research interests are focused on ignorance management, knowledge sharing barriers in technology intensive organisations, and the cost effectiveness of information technology systems and services. John can be contacted at: j.israilidis@ntu.ac.uk

Kayode Odusanya, $\mathrm{PhD}$, is a Lecturer at Nottingham Business School, Nottingham Trent University. His current research interests are focused on technology adoption, sustainability management, and the organisational impact of information systems. Kayode can be reached at: kayode.odusanya@ntu.ac.uk

Muhammad Usman Mazhar, PhD, is a Senior Lecturer in Sustainability in Nottingham Business School at Nottingham Trent University, UK. His research interest is in sustainability, energy \& carbon management, low carbon smart cities, knowledge management and education for sustainable development. 


\title{
Exploring Knowledge Management perspectives in Smart City Research: A review and future research agenda
}

\section{Highlights:}

- Most studies on smart city research tend to focus on technical aspects

- Cities should be seen as information hubs and knowledge repositories

- Citizen-centric initiatives can be the vehicle for future smart city developments

- Developing knowledge sharing and learning capabilities is key for success

\begin{abstract}
:
There is a growing body of literature calling for work on the emerging role of smart cities as information hubs and knowledge repositories. This article reviews the existing smart city literature and integrates knowledge management perspectives to provide an overview of future research directions. By demonstrating the multi-stakeholder relationships involved in smart city development, it takes a crucial step towards looking into the role of knowledge management in future smart city research. Eighty-two peer-reviewed publications were analyzed covering smart city studies in various research domains. The systematic review identifies five different themes: strategy and vision, frameworks, enablers and inhibitors, citizen participation, and benefits. These themes form the basis for developing a future research agenda focused on knowledge sharing and co-learning among cities via three research directions: socio-technical approaches, knowledge sharing perspectives and organizational learning capabilities. The paper also proposes a series of knowledge-driven policy recommendations to contribute towards the UN Sustainable Development Goals.
\end{abstract}

Keywords: knowledge management; smart cities; literature review; policy implications.

\section{Introduction}

The notion of smart city development is emerging as a major response to the rapid urbanization and socio-economic challenges faced by cities globally (Stern et al., 2006; Chourabi et al., 2012; Morris, 2017). According to UN Habitat (2011), the increase in population and rapid demand for energy imposes a greater impact on the environment, with 70 percent of the world's carbon emissions attributed to urban consumption. These challenges also have significant impact on basic amenities such as housing, transportation and healthcare, leading to inadequate transport infrastructure, affordable housing and safe sanitation facilities (Bulkeley, 2013). In view of these observations, there is growing debate around rethinking the focus of the smart city debate to also consider interdependencies and other socio-technical perspectives (Visvizi and Lytras, 2018).

As Caragliu et al. (2011) note, smart cities depend not only on a city's endowment of hard infrastructure (physical capital), but also on the availability and quality of knowledge communication and social infrastructure (human and social capital). This emerging role of cities as information hubs and knowledge repositories is particularly decisive for urban competitiveness as well as enhancing the quality of life (Kumar et al., 2018). However, many smart city projects die after the pilot stage and the lessons learned from previous projects never scale up to inform subsequent implementations (van Winden and van den Buuse, 2017). Moreover, in line with a recent call to incorporate interdisciplinary perspectives within the smart city literature (Lytras and Visvizi, 2018), it is important to understand how the 
smart city literature might integrate knowledge management concepts, such as harvesting lessons learned and fostering stakeholder collaboration, to enhance existing discourse.

Knowledge Management (KM) is of particular relevance for building competitive advantage and creating value proposition (Nonaka and Takeuchi, 1995; Dixon, 2000). From a sociotechnical perspective, it also contributes greatly in sharing lessons learned, reducing implementation costs and fostering organizational learning within and across programs (e.g., Argote and Ingram, 2000; Argote et al., 2003; Cummings, 2004; Hansen, 2002). Although, KM has often been discussed amongst Information System scholars (Alavi and Leidner, 2001; Gold et al., 2001; Newell, 2015), little attention has been given to this particular context of public sector smart city initiatives (Neirotti et al., 2014). In addition, there is limited policy discussion on how knowledge-driven smart cities can help achieve SDGs. This paper reviews the extant smart city literature to identify current theoretical streams and provide further insight into the role of KM in smart city development. Thus, our theoretical contribution is to advance the smart city debate by bringing in KM perspectives to facilitate knowledge sharing and co-learning among cities. It also explores how cities can benefit from the shift towards a knowledge-based viewpoint, deriving policy recommendations for local and national governments. The proposed KM policy perspectives also provide a strategic framework towards achieving specific UN Sustainable Development Goals (SDGs).

In the next section, we proceed with a brief overview of the range of definitions for smart city in the literature. Section 3 provides a description of the search method used to identify relevant research for this review. Section 4 presents the findings of the review along with key implications, while section 5 discusses the proposed way forward for smart city research from a knowledge management perspective. Finally, we present policy implications in section 6 and conclude with section 7 .

\section{Smart city research - relevant definitions}

The term 'smart city' is an interdisciplinary term that embraces several definitions depending on how the word 'smart' is interpreted (Cocchia, 2014). According to the European Commission, smart city is as "a place where the traditional networks and services are made more efficient through the use of digital and telecommunication technologies, for the benefit of its inhabitants and businesses" (European Commission, p. 6). As also echoed by Baccarne et al (2014), smart cities have gained momentum as a conceptual model which embodies a fresh wave of techno-optimism and emphasizes the positive effects of ICT and other innovative technologies in a city, often in combination with multidisciplinary collaborative partnerships. According to Cisco (2014), smart cities should include an integrated urban ICT program suggesting that smart city development includes not only basic services necessary for the smooth operation of transportation networks, water supply and waste management, but also a variety of technology-driven services. Table 1 presents a series of broader definitions as per academic scholars, industry practitioners and policy institutions.

Despite various definitions and explanations, 'smart city' is still a fuzzy concept and there is absence of a commonly accepted definition that encapsulates the complexity and multilayered interconnectedness of new emerging technologies and evolving demands (Nam and Padro, 2011; Albino et al, 2015). Moreover, various technical, organizational and strategic challenges have made it $\mathrm{di} \square$ cult for cities all over the world to secure wellbeing and prosperity in urban spaces (Ruhlandt, 2018). To maximize the benefits offered through smart city projects, Dayan et al., (2017) argue for further research to develop appropriate KM 
practices that support smart city initiatives. Dayan et al., (2007) also highlights the clear need for an advanced geographic knowledge infrastructure for smart city policy. If the objective is to employ emerging technology to offer new generation of services, it is imperative that the new image of modern, knowledge-intensive, cities is explored at length. Lytras and Visvizi (2018) argues that the future of cities is 'smart' and there are various commercial partnerships and research organizations globally attempting to help create smart cities applications.

Table 1: Broad smart city definitions

\begin{tabular}{|c|c|}
\hline Definition & Authors \\
\hline $\begin{array}{l}\text { Smart cities use as IS centric approach to the intelligent use of } \\
\text { ICT within an interactive infrastructure to provide advanced } \\
\text { and innovative services to its citizens, impacting quality of life } \\
\text { and sustainable management of natural resources. }\end{array}$ & Ismagilova et al., (2019) \\
\hline $\begin{array}{l}\text { Smart cities entail strategic initiatives that provide 'green' } \\
\text { solutions aiming at creating better environmental, social and } \\
\text { economic conditions and enhancing cities' attractiveness and } \\
\text { competitiveness. }\end{array}$ & De Jong et al., (2015) \\
\hline $\begin{array}{l}\text { Smart cities have gained momentum as a conceptual model } \\
\text { which embodies a new wave of techno-optimism and } \\
\text { emphasizes the positive effects of ICT and other innovative } \\
\text { technologies, often in combination with multidisciplinary } \\
\text { collaborative partnerships. }\end{array}$ & Baccarne et al., (2014) \\
\hline $\begin{array}{l}\text { Sustainable smart city development encompasses all } \\
\text { dimensions of sustainability including environment, economic } \\
\text { and social well-being of people. }\end{array}$ & Cocchia (2014) \\
\hline $\begin{array}{l}\text { Smart city is a place where traditional networks and services } \\
\text { are made efficient using digital and telecommunication } \\
\text { technologies, for the benefit of inhabitants and businesses. }\end{array}$ & $\begin{array}{l}\text { European Commission } \\
\text { (2014) }\end{array}$ \\
\hline $\begin{array}{l}\text { Smart cities should include an integrated urban ICT that can } \\
\text { overlay on a city and can support delivery of connected urban } \\
\text { services and allow for efficient management of those services } \\
\text { on a global scale. }\end{array}$ & Cisco (2014) \\
\hline $\begin{array}{l}\text { A smart city is an efficient city, a liveable city, as well as an } \\
\text { economically, socially and environmentally sustainable city. } \\
\text { This vision can be realized today, using innovative operational } \\
\text { and information technology, and leveraging meaningful and } \\
\text { reliable real-time data generated by citizens and city } \\
\text { infrastructure. }\end{array}$ & $\begin{array}{l}\text { Schneider Electric } \\
\text { (2014) }\end{array}$ \\
\hline $\begin{array}{l}\text { A smart city is a technologically advanced and modernized } \\
\text { territory with intellectual ability dealing with various social, } \\
\text { economic and technical, aspects of growth based on smart } \\
\text { computing techniques for developing superior infrastructure } \\
\text { and services. }\end{array}$ & Bakici et al., (2013) \\
\hline $\begin{array}{l}\text { Smart city development underpins sustainability curricula in } \\
\text { transportation, energy use and the development of ICT systems. }\end{array}$ & Chourabi et al., (2012) \\
\hline $\begin{array}{l}\text { Smart city denotes an instrumented, interconnected and } \\
\text { intelligent city. 'Instrumented' refers to the capability of } \\
\text { capturing and integrating live real-world data using sensors, } \\
\text { meters, appliances and personal devices. }\end{array}$ & Harrison et al., (2010) \\
\hline
\end{tabular}




\section{Literature search method}

The literature review consisted of several phases. We first visited the review conducted by Ismagilova et al., (2019) which looked at smart city research from an IS perspective. While this review led to valuable insights on smart city research, it was structured to include articles published only in the 'Information Management' category of the 2018 Academic Journal Guide (AJG). In contrast, our review takes a broader view of the smart city literature without restricting to a domain being aware of the multidisciplinary nature of the topic of the smart city. To achieve this goal, we conducted keyword searches (Williams et al., 2009) for the term 'smart city' and its closely-related terms 'digital city', 'intelligent city', 'knowledge city', 'sustainable city', 'ubiquitous city', 'learning city', 'smart community', 'information city', 'virtual city', 'wired city', 'green city', 'knowledge-based city' via the Scopus database. The Scopus database covers a wide range of journals and citation analyses and has been found to be effective in identifying literature published in different research domains (Tamilmani et al., 2019; Hughes et al., 2019).

Next, we included only peer-reviewed journal articles in which smart city was a core concept. Thus, we excluded papers that mentioned 'smart city' or its related terms only in passing and with no description of its meaning. In addition, we focused on scholarly and peer-reviewed articles published in well-known international academic journals to ensure that papers included in our systematic review were of scholarly quality. Furthermore, we selected papers that reported empirical studies or addressed smart city in specific empirical contexts outside the 2018 AJG list. Relevant outputs were found in journal outlets such as European Planning Studies and Urban Geography for example. Motivated by our need to maximize the review's contextualized focus on empirical research, we excluded related literature reviews or conceptual papers on smart cities, although we acknowledge that these papers set the stage for our paper especially with regards to framing the focus of this study's contribution. The selection criteria resulted in a corpus of 82 papers dealing with a variety of different aspects of smart city research. The full list of papers reviewed can be found in the Appendix.

\section{Analysis of the smart city literature}

\subsection{Progress to date in smart city research}

As a result of our search strategy, a wide range of studies were reviewed. Attention to this subject is quite recent as shown in Figure 1. The oldest paper was from 1990 and most papers were either from 2018 (25 papers), 2017 (10 papers) and 2016 (19 papers).

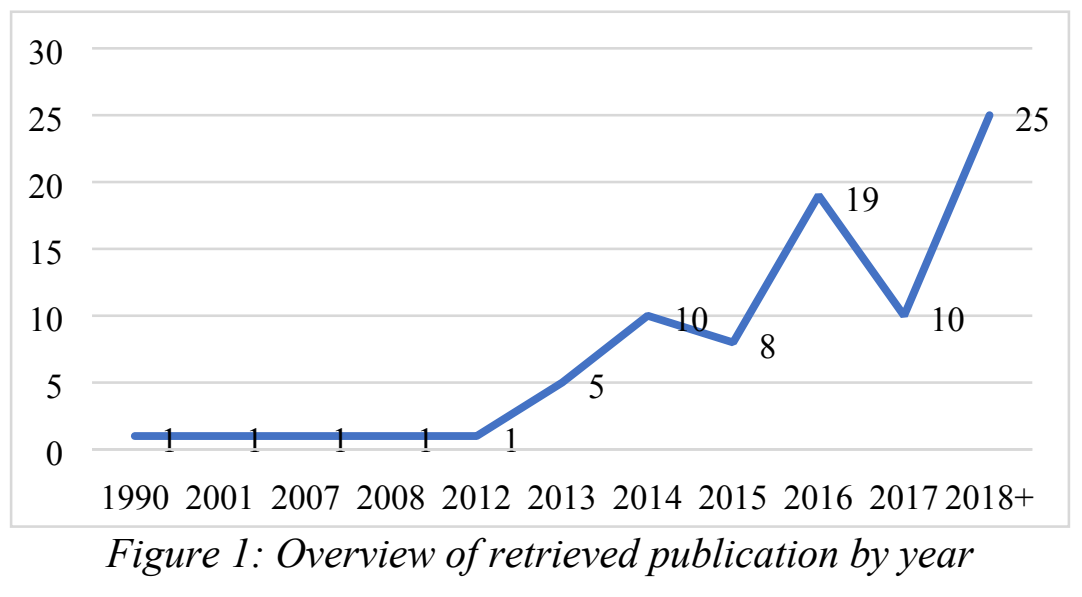


Interestingly and demonstrating the broad scope of smart city research in other research domains, a large part of papers appeared in the Energy Policy and Journal of Cleaner Production (each with 12 papers) both under 'Sector Services' in the 2018 AJG. Within the IS research journals, Government Information Quarterly had the largest number of papers published (nine papers). Most of our sample papers were published in 2014 or after; only twelve papers were published before 2014 and one paper was published before the year 2000 .

From a theoretical standpoint, the trend we observe is that existing smart city research is fragmented. In almost two-thirds $(63 \%)$ of the papers in our sample, the authors did not mention the use of any theory/framework, with the remaining (37\%) utilizing only one theory in their analysis, while none of the papers mentioned the use of multiple theories in their work. This suggests that while smart city research is gradually evolving and developing into an independent research area, the limited use of theory may suggest a significant deficit in scholarly engagement. Indeed, the lack of use of multiple theories could be a sign of a less mature areas of research according to Keathley-Herring et al., (2016). There is a need for 'active' theoretical trend-setting smart city research that integrates the multiple stakeholders that are involved in enabling smart cities. Such research we would argue could be tailored to the idiosyncrasies of the organizations such as city councils/governments as a central unit of analysis in view of the role they play in facilitating investments and action on smart city projects.

From a geographical viewpoint, our review reveals that only six empirical studies (7\%) used data collected from two or more countries. Most were conducted within a single country and these were dominated the focus on developed countries in Europe (5\%). Of these, most of the research $(31 \%)$ were conducted in the UK followed by those conducted in Italy $(21 \%)$.

Outside the UK, the most focus of smart city research has focused on Asian countries $(20 \%)$, particularly within the contexts of China and India. This is followed by research that has been conducted in the US (10\%). It is worth noting that no study in our sample was focused in Africa and as the review by Ismagilova et al., (2019) also note, more comparative studies are needed with more cross-cultural focus. Hence, there is still much we do not know about smart city initiatives in numerous geographical contexts. However, recent studies (Giest, 2017; Cledou et al., 2018) have begun to undertake a multi-country perspective with Giest (2017) looking at the challenges UK city councils face when dealing with big data in the context of carbon emission reduction, while Cledou et al., (2018) propose a taxonomy for planning and designing smart mobility services for the development of smart mobility initiatives. While the insights offered by these studies are important, there is a need for smarter city research to drive theoretical innovations via the insights that can be drawn from a broader and multicountry focus. Moreover, such studies are likely to pave the way for both core scientific and social science inquiry that could enable effective learning and knowledge management in smart city research.

Further to the progress in smart city research, we elaborate on the key themes based on existing literature. In the next section, we discuss the overarching themes that emerged from our analysis. In this section, we discuss the overarching themes that emerged.

\subsection{Thematic map of the field}

We classified and analyzed the studies to better understand key themes that have been discussed within the smart city literature. We identified five different themes, namely strategy 
and vision in the context of smart cities, smart city concepts and frameworks, enablers/inhibitors of smart city development, citizen participation in smart cities, and benefits of smart cities.

Numerous studies - 24 (29\%) of the 82 empirical studies focus on strategy and vision in the context of the smart city debate. White (2016) argues for example that the narrative surrounding smart city as "a generalization of a complex and contested imaginary" (p. 577) draws on three recurring crises: massive urbanization, global climate change and fiscal austerity. The study posits that these crises cannot be generalized globally. Rather, future conversations on smart city should clarify contextual challenges and not overlook differences in challenges and politics at different national contexts. Considering the expansion of digital consumerism as a premise for smart city participation, Viitanen and Kingston (2014) argues for the need to promote openness and choice about the presence and influence of ICTs in cities and in the private lives of citizens. These studies suggest different approaches to change the narrative surrounding the discussion of smart city initiatives.

We identified a second category of studies - $20(24 \%)$ of the empirical sample - that developed frameworks within the smart city literature. Huston et al., (2015) developed a smart and sustainable urban regeneration (smart-SUR) framework that combines 'institutional', 'project' and innovative 'funding' components. Lugaric and Krajcar (2016) developed a framework bringing together energy, economy and environmental sciences, to provide cities with a systematic approach to implement smart city initiatives. In addition, Reyna and Chester (2015) proposed a framework for assessing how greenhouse gas emissions of urban building changes over time. In general, the review shows that there is a fragmented discourse regarding the frameworks developed within the smart city literature. We stress the need for frameworks that offer a more holistic understanding of the multistakeholder processes involved in smart city projects.

Another set of studies - $22(27 \%)$ of the empirical papers - focused on the enablers and inhibitors of successful smart city projects. For instance, Zawieska and Pieriegud (2018) investigate the relationship between the implementation of smart city solutions and sustainable transport. Their findings showed that the smart city solutions can significantly contribute to mitigating transport-related Green House Gas (GHG) emissions in urban areas. In addition, Grimaldi et al., (2017) argue for the crucial role universities play in preparing undergraduates to the professions required for smart city transformations. Although these studies identify how different factors are likely to influence the outcome of smart city initiatives, the lack of comparative studies make it difficult to quantify the significance of tested relationships.

A fourth category of studies $-7(9 \%)$ of the empirical sample focused on the participation of citizens in smart city implementation. This small number of studies in this theme suggests that the participation of citizens is rarely viewed as part of the broader smart city stakeholder ecosystem. For example, Buchs et al., (2018) portrayed how participation in a carbon calculator interview increased awareness of ways in which individuals could reduce their carbon footprint. This finding however did not translate into significant changes in long-term behaviors. Behrendt (2016) develops the concept of smart velomobility - concerned with networked practices, systems and technologies of cycling. The study also went further to focus on how riders of a networked fleet of e-bikes discuss experience of smart velomobility. 
In addition, Burchell et al., (2016) showed that attempts to foster community action through weekly email communications fostered long-term engagement with energy consumption feedback. The aforementioned studies show that the role citizens play in smart city implementation is an emerging consideration in smart city research.

The final category contained articles - $9(11 \%)$ - that examined the potential benefits of smart city implementation. Benefits refer to the potential outcomes resulting from smart city participation. For example, Chatterjee et al., (2018) examined factors affecting successful implementation of information system enabling IoT coupled with Artificial Intelligence in four proposed smart cities in India. The study finds that users' perceived satisfaction to use IoT and perceived information quality regarding IoT both significantly affect the potential net benefit of using IoT in smart cities. In addition, Mendoza et al., (2015) portray how smart cities provide energy-efficient mobility solutions through the ecological design (eco-design) of urban elements. Given that infrastructure eco-design is key to mitigate environmental impacts of urban mobility, we suggest more research is needed to explicitly communicate the benefits of smart city implementation for individual stakeholders

\subsection{System-level analysis of the field}

Furthermore, drawing on the work of Croom et al., (2000) and Mizruchi and Marquis (2006), we examined three levels of analysis of stakeholder interaction within the smart city literature: (i) the individual level (egocentric): which considers a single actor unit of analysis, e.g. an individual city or case study; (ii) the chain level (cliques): which considers two or more actors as unit of analysis, e.g. a set of smart city projects or a group of cities; (iii) the network level (sociocentric): which considers a network of interlinked or interconnected actors. Table 2 presents a summary of our findings along with the themes identified and key implications for future studies.

Within these themes, it is important to note that we observed evident links between KM constructs and the clusters identified. For example, increasing participation of citizens is closely linked to the socio-technical aspects of smart city development and particularly leadership empowerment and socialization. Besides, there is growing debate among scholars for the need to reassess the current design and management of smart cities to embed KM perspectives to ensure that certain outcomes are achieved (Bakici et al., 2013; Ardito et al., 2018). Similarly, studies that focused on process enabling factors in smart city research appear to be closely linked with the elements of trust and collaboration. In addition, studies that evaluate strategies and vision were mainly associated and linked with knowledge sharing and organizational learning. Although elements of KM appear to be evident across all themes, there are only a few papers making explicit references to the role of knowledge sharing in smart city replication. A thorough analysis of these papers, which is presented in detail in the following section, allows us to propose avenues for future research on smart cities from a non-technical, knowledge-focused perspective. 
Table 2: Smart city research themes and key implications

\begin{tabular}{|c|c|c|c|c|c|c|}
\hline Themes & Description of themes & Egocentric & Cliques & Sociocen & Findings & Implications \\
\hline Citizens & $\begin{array}{l}\text { Fostering participation } \\
\text { of citizens (citizen- } \\
\text { centric) }\end{array}$ & 5 & 0 & 2 & \multicolumn{2}{|c|}{$\begin{array}{l}\text { The role citizen as key stakeholders have } \\
\text { been widely discussed by several scholars. } \\
\text { However, the table shows that the discussion The participation of citizens should be } \\
\text { is mainly taking place at the individual level. evaluated as part of a network of } \\
\text { This means that the participation of citizens is agents } \\
\text { rarely viewed as part of the broader smart city } \\
\text { stakeholder ecosystem. }\end{array}$} \\
\hline Benefits & $\begin{array}{l}\text { Potential outcomes } \\
\text { and impact of smart } \\
\text { city projects }\end{array}$ & 2 & 4 & 3 & $\begin{array}{l}\text { Benefits refer to the potential outcomes } \\
\text { resulting from smart city participation. The } \\
\text { review shows that fewer studies have } \\
\text { examined benefits that may accrue at the } \\
\text { individual-level. }\end{array}$ & $\begin{array}{l}\text { More research is needed to explicitly } \\
\text { communicate the benefits of smart city } \\
\text { implementation for individual } \\
\text { stakeholders }\end{array}$ \\
\hline Enablers & $\begin{array}{l}\text { Examining facilitators } \\
\text { of smart city } \\
\text { implementation }\end{array}$ & 9 & 9 & 4 & $\begin{array}{l}\text { Research investigating the enablers/inhibitors } \\
\text { of smart city implementation has majorly } \\
\text { been conducted at the individual and chain- } \\
\text { level. }\end{array}$ & $\begin{array}{l}\text { More studies are needed to examine } \\
\text { system-level enablers of smart city } \\
\text { implementation }\end{array}$ \\
\hline Frameworks & $\begin{array}{l}\text { Models and } \\
\text { theoretical concepts } \\
\text { used in smart city } \\
\text { research }\end{array}$ & 7 & 7 & 6 & $\begin{array}{l}\text { Existing literature portrays a balanced } \\
\text { approach on the use of frameworks }\end{array}$ & $\begin{array}{l}\text { Future studies should take a more } \\
\text { integrative approach in } \\
\text { conceptualizing the relationships } \\
\text { pertaining to smart city } \\
\text { implementation }\end{array}$ \\
\hline Strategy & $\begin{array}{l}\text { Future direction and } \\
\text { vision in smart city } \\
\text { literature }\end{array}$ & 9 & 13 & 2 & $\begin{array}{l}\text { The discussion around strategic approaches to } \\
\text { smart city implementation is limited at the } \\
\text { network level. Most have majorly focused on } \\
\text { strategies at the individual or chain levels. }\end{array}$ & $\begin{array}{l}\text { More studies are needed to move away } \\
\text { from the current siloed perspectives } \\
\text { onto a more unified and integrated } \\
\text { strategic thinking and planning for } \\
\text { future smart city developments. }\end{array}$ \\
\hline
\end{tabular}




\section{The way forward - the knowledge management perspective}

The systematic review showed thematic intersections among emerging elements of smart cities development, generating an argument that themes could together form a conceptual approach for improving smart city KM mechanisms. The synthesis in this section focuses on the analysis of emerging research thrusts from the review and their properties in developing a framework that enables knowledge sharing and co-learning among cities.

\subsection{Sociotechnical approaches to smart city development}

The concept of smart city has been predominantly drawing on innovative ICT-based practices to make cities smarter. Nam and Pardo (2011) state that a set of the common multidimensional components underlying smart cities fall under three dimensions, namely technology, people, and institutions of smart city. This includes effective integration of city infrastructure and technology-mediated services, social learning for facilitating human infrastructure, and governance for institutional improvement and citizen engagement. Therefore, key characteristic in the development and operation of smart cities is being people-oriented (Cocchia, 2014). City implementation managers must realize that technology by itself will not make a city smarter (Meijer and Bolívar, 2016). Although the combination of the IoT and big data present new challenges for achieving the goal of future smart cities (Hashem et al., 2016), big data indeed plays dominant role in effecting knowledge cocreation which impacts re-organizing knowledge management and usage cycle in knowledgedriven organizations (Acharya et al., 2018; Duan et al., 2019). 'Smart citizens' are required for the delivery of outputs, thus active engagement of people in energy/carbon reduction and the provision of personalized information significantly increase their awareness of key activities they could do to reduce their carbon footprint (Büchs et al, 2018; Nyberg, 2018). The review further suggests that citizens' quality of life is explained by four domains; sociostructural relationships, environmental wellbeing, material well-being and community integration (Macke et al., 2018). Thus, the quality of life of communities is predominantly based on how information and knowledge is handled and shared across different layers. Arguably, important socio-technical and psychological barriers to carbon reduction persist and these need to be addressed by more ambitious climate mitigation policies (Büchs et al, 2018). From a KM perspective, trust, whether affect-based or cognition-based, can help overcome some of those obstacles as it has a significant positive effect on people's willingness to share and use tacit knowledge (Holste and Fields, 2010). This in turn can help to effectively engage communities and cities in adopting smart technologies and collaborating with others for successfully implementing various smart initiatives.

Although there is a rising global push for upgrading conventional cities to smart, the review identified a number of inhibiting factors that can hinder smart city development. For example, the sustainable governance of transport systems remains a significant challenge for policy makers worldwide (Zawieska and Pieriegud, 2018). Furthermore, while technology is argued as one of the main drivers for smart city development with the aim to increase the life quality of their inhabitants (Bakici et al., 2013), Hens et al (2018) make an interesting contribution noting that ideas on cleaner production, environment and sustainable development fundamentally illustrate that challenges cannot be solved by technology or socio-economic data alone. Other barriers may also include, amongst others, the lack of organizational participatory stakeholder collaboration to obtain and decompose data from both tacit and explicit sources on technology, socio-economics, policy and legal perspectives (Shin, 2014; Shin and Jin Park, 2017). This strengthens the case to look at smart city development in a wider, more societal scope, and the transition towards a more informationfriendly and knowledge-driven system. 
Leveraging new knowledge to create next generation technologies and novel tools is crucial in smart city development. As De Luca et al., (2018) point out, infrastructure to produce electric energy and meet the thermal energy demands of modern cities depends on an array of different technologies ranging from photovoltaic panels and biogas cogeneration plants to thermal solar panels and wind turbine systems. In addition, Zygiaris (2012) also portrays the crucial role technology plays in driving ecosystem planning towards smart city development within a particular urban context. Both De Luca et al., (2018) and Zygiaris (2012) provide evidence buttressing the role technology plays in successfully achieving smart city outcomes. We would argue therefore that technology as a supporting mechanism can conjoin hard and soft perspectives which are both equally important in the strategic and operational facets of managing smart and sustainable cities.

\subsection{Integrating knowledge sharing perspectives}

As organizational effectiveness is built upon individual and collective knowledge, the involvement of smart city stakeholders in knowledge sharing (e.g., either through face to face or virtual Communities of Practice) has become one of the most prominent strategies for optimizing urban systems. Knowledge sharing is leveraged for effective and sustainable service delivery (Alavi and Leidner, 2001; Argote and Ingram, 2000) as well as a variety of additional desirable organizational outcomes such as increased productivity (Argote et al., 2000), decreased task completion time (Hansen, 2002); increased organizational learning and innovativeness (Jackson et al., 2006). Extant literature recognizes a set of variables that moderate this relationship, i.e., enable or prevent, knowledge sharing in organizations. Examples include constructs such as trust, anticipated reciprocal relationships, identification, image, organizational rewards, knowledge self-efficacy, and loss of knowledge power (e.g., Davenport and Prusak, 1998; Jarvenpaa and Staples, 2000; Bock et al., 2005; Kankanhalli et al., 2005; Wasko and Faraj, 2005; Chiu et al., 2006).

Arguably, extant smart city literature suggests a gap in sufficiently documenting and sharing strategic and operational narratives, highlighting the need for further work in this context (Kaklauskas et al., 2018). Current discussions are mainly centerd around local or regional frameworks, focusing on eco-economic dimensions and environmental aspects, such as ecological empowerment, sustainable consumption of resources and attitudinal changes to land use and urban development (Fu and Zhang, 2017; Lugaric and Krajcar, 2016; Tao et al., 2016). The synthesis of available literature suggests that not much-encompassing documentation exists in the blend of KM, learning and sharing strategies in either the design or development of smart cities. This highlights the need to propose an in-depth discussion on the changing spatial concepts of knowledge precincts and their vital role for the knowledge-based urban development of cities (Yigitcanlar et al., 2008).

Considering that smart cities are based on the collaboration between firms, end-users and local stakeholders, replication, scaling and eco-system seeding is seen as the vehicle for shaping future developments (Staffans and Horelli, 2014). Although technology plays a key role in achieving this transformation (Bakici et al., 2013), being aware of the considerable energy savings and carbon emission reductions through the use of digital infrastructures and data management systems is argued not to suffice due to not knowing whether the costs and benefits under-gridding the sustainability of city-districts are shared equally (Deakin and Reid, 2018). Knowledge, whether tacit or explicit, is corrigible and time-bound; thus, the lack of equal coordination in scaling-up smart cities requires embedding knowledge sharing 
practices to achieve replication while offering the opportunity for confirmation or disconfirmation of theory (Lamal, 1990).

\subsection{Developing organizational learning capabilities}

Besides the rational and integrated application of new technologies, collaboration of multiple stakeholders, and integration of multiple urban energy domains mainstreamed in energy specific targets, can foster sustainable smart city development (Mosannenzadeh et al., 2017). Further, significant arguments are discussed advocating the need to re-politicize the debates on Smart Cities and put citizens back at the center of the urban debate (March and RiberaFumaz, 2016). As such, green leadership, whereby cities can shape urban climate change policy and outcomes, is often used by policy makers and stakeholders to increase buy-in of residents and those involved in the implementation of the strategy through learning within the region and between (peer) cities (Affolderbach and Schulz, 2017).

Fostering learning, within and between smart city stakeholders such as local authorities and residential citizens, is key for knowledge creation and development (Pawlowsky, 2001). As Fiol and Lyles (1985: 804) note "learning enables organizations to build an organizational understanding and interpretation of their environment... it results in associations, cognitive systems, and memories that are developed and shared by members of the organization". Leonard-Barton (1995) notes that core capabilities in organizations are seen as the 'wellspring' of organizational learning processes. Smart cities offer the potential to harness such capabilities as their competitive advantage depends on the knowledge and skills they possess in a distinct area. The critical question therefore of maximizing knowledge creation lies in mobilizing tacit knowledge in smart cities and transferring it to the group and organizational level in order for collective system-levels to learn (Pawlowsky, 2001).

Smart cities should be embedding learning practices within their structures to better understand the multiplicity and complexity of urban innovation. As Valdez et al., (2018) note, there is a need to overcome informational gaps and uncertainties and although the competent performance of smart city processes can be deceptively information-intensive, city managers and transport providers are the main keepers of information. "Shifting this relationship so users become information generators and holders, making the invisible visible, is valued and would be a radical step" (Valdez et al., 2018: 154).

Since core rigidities and capabilities of organizations are considered as 'interlocked systems of knowledge bases and flows' (Leonard-Barton, 1995), individual knowledge and experiences which often are implicit in nature have to be articulated and experienced by all parties at interest. Barriers for the implementation of effective learning and collaboration in smart cities include research and development, cultural dynamics, and economic strength, amongst others (Romão et al., 2018). This tends to influence the rate of replication, the validity of data and quality of overall output when assessing learning-based capabilities. In order to promote organizational learning, different activities such as integrated problem solving across different cognitive and functional barriers, implementation of new methodologies, experimentation and importing know-how from outside are suggested (Leonard-Barton, 1995).

\section{Policy recommendations}

This paper has reviewed the concept of smart city with a focus on knowledge management to share information and facilitate learning in cities. Visvizi and Lytras (2018) argue that smart city research needs to feed into policy-design and policymaking processes for transforming 
cities. In this section, we present policy recommendations as informed by the review that has been conducted.

First, practitioners in local authorities are implementing a range of smart city projects offering insights and lessons learned in the form of what works and what does not and why. Arguably, these lessons learned are not captured systematically to inform future smart city practice and policies. At present, polices related to smart city initiatives are very much focused on addressing technical issues as evidenced by the review (Nam and Padro, 2011; Ruhlandt, 2018). Addressing non-technical aspects does not appear to be a priority when developing and implementing policies both locally and nationally. Lessons learned from previous smart city projects can inform local and national policy if captured appropriately (Argote and Ingram, 2000). Consistency on how knowledge is captured and shared is key, hence a wide-system framework to support documenting, storing and maintaining records of performance and actions undertaken needs to be developed. On the other hand, knowledge is often tacit in local authorities and can be difficult to capture and harness (Pawlowsky, 2001; Holste and Fields, 2010). Thus, ways in which tacit knowledge can be made more explicit with appropriate knowledge management systems in place needs to be investigated for future practice and policymaking.

Second, although ICT integration is one of the core determinants of smart city development, stakeholder engagement is a critical component for the successful implementation of smart cities (Shin and Jin Park, 2017; Hunter et al., 2018). Smart city projects involve various city stakeholders such as public, private and civic which all need to collaborate and innovate together. However, the complex dynamics where different stakeholders' interests meet and collide can hinder efforts in the area of replication and scaling up. Stakeholder engagement is relatively unexplored (van Winden and van den Buuse, 2017) and needs to be streamlined to ensure successful outcomes. At present, cities tend to work in isolation and communication is often ad-hoc and more through individual relationships. As Winden and van den Buuse (2017) argue, project participants rarely openly discuss each other's smart city perspectives and ambitions and they do not build mechanisms that ease the transition to the replication and upscaling phase. A strategy on how to engage parties at interest will help to address such issues around governance, mapping and communication and make the smart city transition journey smoother. In a local authority context, middle managers are mainly responsible for implementing smart city initiatives and often seem to follow a narrow top-down communication approach for delivering projects. Wider stakeholder engagement of city leaders with citizens can drive change in terms of resources and champion the cause of innovation (Fernandez and Rainey, 2006).

The policy recommendations have a direct impact on several UN SDGs and can help to address the challenges cities are facing. Table 3 shows high-level policy recommendations including how smart city policies can help achieve certain SDGs, specifically SDG 9: Industry, Innovation and Infrastructure, SDG 11: Sustainable Cities and Communities, SDG 13: Climate Action and SDG 17: Partnerships for the Goals. These SDGs are interconnected and often the success on one will help achieve the other associated goals. The proposed recommendations should be seen in line with existing efforts on promoting institutional change and realizing the political nature of socio-technical governance for developing smart cities (Meijer and Bolívar, 2016).

Table 3: KM policymaking perspectives on the UN SDGs

\begin{tabular}{|l|l|l|}
\hline SDGs & Description & Policy making perspectives \\
\hline
\end{tabular}




\begin{tabular}{|c|c|c|}
\hline $\begin{array}{l}\text { SDG 9: } \\
\text { Industry, } \\
\text { Innovation } \\
\text { and } \\
\text { Infrastructure }\end{array}$ & $\begin{array}{l}\text { The creation of new } \\
\text { knowledge builds a more } \\
\text { resilient infrastructure and } \\
\text { fosters innovation. } \\
\text { Mechanisms to ensure } \\
\text { replication of lessons } \\
\text { learned can promote } \\
\text { inclusive and sustainable } \\
\text { industrialization. }\end{array}$ & $\begin{array}{l}\text { Policy around the storage, reuse and } \\
\text { maintenance of knowledge is nebulous. As } \\
\text { evident through the review, more is needed to } \\
\text { ensure effective reuse of knowledge in } \\
\text { achieving replication and maximizing return } \\
\text { on investment. This is in line with UN's target } \\
\text { in providing affordable and equitable access } \\
\text { for all. }\end{array}$ \\
\hline $\begin{array}{l}\text { SDG 11: } \\
\text { Sustainable } \\
\text { Cities and } \\
\text { Communities }\end{array}$ & $\begin{array}{l}\text { Citizen-centric smart city } \\
\text { initiatives make cities and } \\
\text { human settlements } \\
\text { inclusive, resilient and } \\
\text { sustainable. }\end{array}$ & $\begin{array}{l}\text { The review has highlighted a lack of research } \\
\text { on viewing the participation of citizens as part } \\
\text { of a broader smart city stakeholder ecosystem. } \\
\text { Policy needs to be reformed to ensure that } \\
\text { citizens are knowledge keepers as well as } \\
\text { knowledge generators. }\end{array}$ \\
\hline $\begin{array}{l}\text { SDG 13: } \\
\text { Climate } \\
\text { Action }\end{array}$ & $\begin{array}{l}\text { Lessons learnt from carbon } \\
\text { reduction, energy and } \\
\text { mobility projects in cities } \\
\text { raise awareness and human } \\
\text { and institutional capacity } \\
\text { on climate change } \\
\text { mitigation, adaptation and } \\
\text { impact reduction. }\end{array}$ & $\begin{array}{l}\text { Climate change mitigation and adaptation } \\
\text { measures need to be better integrated into both } \\
\text { national and local policies, strategies and } \\
\text { planning procedures. Knowledge generated } \\
\text { should inform future policy and the use of } \\
\text { technology can strengthen communications } \\
\text { and help facilitate knowledge acquisition and } \\
\text { transfer to develop actions. }\end{array}$ \\
\hline $\begin{array}{l}\text { SDG 17: } \\
\text { Partnerships } \\
\text { for the Goals }\end{array}$ & $\begin{array}{l}\text { Collaboration and } \\
\text { multiagency work } \\
\text { strengthen the means of } \\
\text { implementation and } \\
\text { revitalizes the global } \\
\text { partnership for sustainable } \\
\text { development. }\end{array}$ & $\begin{array}{l}\text { The review has pointed out the need to } \\
\text { develop organizational learning capabilities } \\
\text { that help promote dialogue, learning, cross } \\
\text { team collaboration and knowledge sharing } \\
\text { within and across urban communities. This } \\
\text { supports UN's goals aiming at enhancing } \\
\text { global macroeconomic stability, including } \\
\text { through policy coordination and policy } \\
\text { coherence. }\end{array}$ \\
\hline
\end{tabular}

\section{Conclusions}

This article reviews the existing smart city literature and integrates knowledge management perspectives to inform future research directions. It identifies three key research thrusts: (1) sociotechnical approaches to smart cities, (2) integrating knowledge sharing perspectives and (3) developing organisational learning capabilities. These are emerging and interlinked elements of smart city development and present a conceptual approach for improving smart city knowledge management mechanisms. Smart cities have multidimensional components such as ICT applications, citizen engagement and governance. However, the concept of 'smart city' has been mainly drawing on technical aspects and a few economic theories. On the other hand, it is argued the current technically inclined discourse is unlikely to encapsulate more nuanced contributions of key stakeholders involved in smart city initiatives. For example, citizens have an important role in ensuring they imbibe supportive attitudinal behaviours for successful smart city projects.

Various academic studies have given attention to smart cities and their governance procedures in different city contexts, but the fragmentation in delivery approaches makes for a confusing debate in the existing academic literature. This review provides evidence that in- 
depth research on the development of smart cities from a knowledge management and learning perspective has remained scant and identifies research thrusts for future research directions. This can help share lessons learned and provide both practical and policy recommendations based on feedback from projects to enhance replication.

Although this paper explores smart cities through the lens of knowledge management, it has only looked at evaluating specific knowledge strategies and themes. For example, future studies might want to explore other strategic management perspectives such as innovation and institutional theories to see how they can inform the smart city debate. Also, additional studies may advance our understanding of the smart city literature by employing useful theories to develop testable propositions. This will also strengthen the case to look at smart city development in a wider scale for the transition towards a more information-friendly and knowledge-driven system. 


\section{References}

Acharya, A., Singh, S.K., Pereira, V. and Singh, P. (2018). Big data, knowledge co-creation and decision making in fashion industry. International Journal of Information Management, $42,90-101$.

Andersson, I. (2016). Green cities' going greener? Local environmental policy-making and place branding in the 'Greenest City in Europe. European Planning Studies, 24(6), 11971215.

Ardito, L., Ferraris, A., Petruzzelli, A.M., Bresciani, S. and Del Giudice, M. (2018). The role of universities in the knowledge management of smart city projects. Technological Forecasting and Social Change.

Affolderbach, J. and Schulz, C. (2017) Positioning Vancouver through urban sustainability strategies? The Greenest City 2020 Action Plan. Journal of Cleaner Production, 164, pp. 676-685.

Alavi, M., \& Leidner, D. (2001). Knowledge management and knowledge management systems: conceptual foundations and research issues. MIS Quarterly, 1: 107-136.

Albino, V., Berardi, U., \& Dangelico, R. M. (2015). Smart cities: Definitions, dimensions, performance, and initiatives. Journal of Urban Technology, 22(1), 3-21.

Argote, L., \& Ingram, P. (2000). Knowledge transfer: A basis for competitive advantage in firms. Organizational Behavior and Human Decision Processes, 82: 150-169.

Argote, L, Ingram, P, Levine, J. M., \& Moreland, R.L. (2000). Knowledge transfer in organizations: Learning from the experience of others. Organizational Behavior and Human Decision Processes, 82: 1-8.

Argote, L., McEvily, B., \& Reagans, R. (2003). Managing knowledge in organizations: An integrative framework and review of emerging themes. Management Science, 49(4), 571-582.

Axelsson, K., \& Granath, M. (2018). Stakeholders' stake and relation to smartness in smart city development: Insights from a Swedish city planning project. Government Information Quarterly, 35(4), 693-702.

Baccarne, B., Mechant, P., \& Schuurman, D. (2014). Empowered cities? An analyzis of the structure and generated value of the smart city Ghent. In Smart City (pp. 157-182). Springer, Cham.

Bakici, T., Almirall, E., \& Wareham, J. (2013). A smart city initiative: the case of Barcelona. Journal of the Knowledge Economy, 4(2), 135-148.

Bazán, J., Rieradevall, J., Gabarrell, X., \& Vázquez-Rowe, I. (2018). Low-carbon electricity production through the implementation of photovoltaic panels in rooftops in urban environments: A case study for three cities in Peru. Science of The Total Environment, 622, 1448-1462.

Behrendt, F. (2016). Why cycling matters for smart cities. Internet of bicycles for intelligent transport. Journal of Transport Geography, 56, 157-164.

Belanche-Gracia, D., Casaló-Ariño, L. V., \& Pérez-Rueda, A. (2015). Determinants of multiservice smartcard success for smart cities development: A study based on citizens' privacy and security perceptions. Government information quarterly, 32(2), 154-163.

Bifulco, F., Tregua, M., Amitrano, C. C., \& D'Auria, A. (2016). ICT and sustainability in smart cities management. International Journal of Public Sector Management, 29(2), 132147.

Bennett, M., \& Newborough, M. (2001). Auditing energy use in cities. Energy Policy, 29(2), 125-134. 
Bock, G.-W., Zmud, R.W., Kim, Y.-G. \& Lee, J-N. (2005). Behavioral intention formation in knowledge sharing: examining the roles of extrinsic motivators, social-psychological forces, andorganizational climate. MIS Quarterly, 29: 87-111.

Bresciani, S., Ferraris, A., \& Del Giudice, M. (2018). The management of organizational ambidexterity through alliances in a new context of analyzis: Internet of Things (IoT) smart city projects. Technological Forecasting and Social Change, 136, 331-338.

Büchs, M., Bahaj, A.S., Blunden, L., Bourikas, L., Falkingham, J., James, P., Kamanda, M., \& Wu, Y. (2018) Promoting low carbon behaviours through personalised information? Longterm evaluation of a carbon calculator interview. Energy Policy, 120, 284-293.

Bulkeley, H. (2013). Cities and climate change. London: Routledge.

Burchell, K., Rettie, R., \& Roberts, T. C. (2016). Householder engagement with energy consumption feedback: the role of community action and communications. Energy

Policy, 88, 178-186.

Caponio, G., Massaro, V., Mossa, G., \& Mummolo, G. (2015). Strategic energy planning of residential buildings in a smart city: a system dynamics approach. International Journal of Engineering Business Management, 7, 20.

Caprotti, F. (2014). Critical research on eco-cities? A walk through the Sino-Singapore Tianjin Eco-City, China. Cities, 36, 10-17.

Caprotti, F., Springer, C., \& Harmer, N. (2015). 'Eco'For Whom? Envisioning Eco-urbanizm in the Sino-Singapore Tianjin Eco-city, China. International Journal of Urban and Regional Research, 39(3), 495-517.

Caragliu, A., Del Bo, C., \& Nijkamp, P. (2011). Smart cities in Europe. Journal of Urban Technology, 18(2), 65-82.

Carè, S., Trotta, A., Carè, R., \& Rizzello, A. (2018). Crowdfunding for the development of smart cities. Business Horizons, 61(4), 501-509.

Chatterjee, S., Kar, A. K., \& Gupta, M. P. (2018). Success of IoT in smart cities of India: an empirical analyzis. Government Information Quarterly, 35(3), 349-361.

Chong, M., Habib, A., Evangelopoulos, N., \& Park, H. W. (2018). Dynamic capabilities of a smart city: An innovative approach to discovering urban problems and solutions. Government Information Quarterly, 35(4), 682-692.

Chourabi, H., Nam, T., Walker, S., Gil-Garcia, J.R., Mellouli, S., Nahon, K., Pardo, T.A. and Scholl, H.J. (2012). Understanding smart cities: An integrative framework. In the 45th

Hawaii International Conference on System Science (HICSS), 4-7 January, Maui, HI, 22892297.

Chiu, C. M., Hsu, M. H., \& Wang, E. T. (2006). Understanding knowledge sharing in virtual communities: An integration of social capital and social cognitive theories. Decision Support Systems, 42(3), 1872-1888.

Cisco (2014). Cisco Smart + Connected Communities: Envisioning the Future of Cities Now. San Jose, CA: Cisco Systems, Inc.

Cledou, G., Estevez, E., \& Barbosa, L. S. (2018). A taxonomy for planning and designing smart mobility services. Government Information Quarterly, 35(1), 61-76.

Coaffee, J. (2008). Risk, resilience, and environmentally sustainable cities. Energy Policy, 36(12), 4633-4638.

Cocchia A. (2014) Smart and Digital City: A Systematic Literature Review. In: Dameri R., Rosenthal-Sabroux C. (eds) Smart City. Progress in IS. Springer, Cham. 
Croom, S., Romano, P., \& Giannakis, M. (2000). Supply chain management: an analytical framework for critical literature review. European Journal of Purchasing \& Supply Management, 6(1), 67-83.

Cugurullo, F. (2016). Urban eco-modernisation and the policy context of new eco-city projects: Where Masdar City fails and why. Urban Studies, 53(11), 2417-2433.

Cugurullo, F. (2018). Exposing smart cities and eco-cities: Frankenstein urbanizm and the sustainability challenges of the experimental city. Environment and Planning A: Economy and Space, 50(1), 73-92.

Cummings, J. N. (2004). Work groups, structural diversity, and knowledge sharing in a global organization. Management Science, 50(3), 352-364.

Davenport, T. and Prusak, L. (1998). Working Knowledge: How Organizations Manage What They Know. Cambridge, MA: Harvard Business School Press.

Dayan, R., Heisig, P., \& Matos, F. (2017). Knowledge management as a factor for the formulation and implementation of organization strategy. Journal of Knowledge Management, 21(2), 308-329.

Deakin, M. and Reid, A., 2018. Smart cities: Under-gridding the sustainability of citydistricts as energy efficient-low carbon zones. Journal of Cleaner Production, 173, pp.39-48.

De Jong, M., Joss, S., Schraven, D., Zhan, C., \& Weijnen, M. (2013). Sustainable-SmartResilient-Low Carbon-Eco-Knowledge Cities. J. Clean. Prod, 108, 25-38.

De Jong, M., Joss, S., Schraven, D., Zhan, C., \& Weijnen, M. (2015). Sustainable-smartresilient-low carbon-eco-knowledge cities; making sense of a multitude of concepts promoting sustainable urbanization. Journal of Cleaner Production, 109, 25-38.

De Luca, G., Fabozzi, S., Massarotti, N., \& Vanoli, L. (2018). A renewable energy system for a nearly zero greenhouse city: Case study of a small city in southern Italy. Energy, 143, 347362.

Dixon, N. M. (2000). Common knowledge: How companies thrive by sharing what they know. Boston: Harvard Business School Press.

Duan, Y., Edwards, J.S., \& Dwivedi, Y.K. (2019). Artificial intelligence for decision making in the era of Big Data-evolution, challenges and research agenda. International Journal of Information Management, 48, 63-71.

European Commission. (2014). A digital agenda for Europe. Luxembourg: Publications Office of the European Union.

Fernandez, S. \& Rainey, H.G. (2006). Managing successful organizational change in the public sector. Public Administration Review, 66(2), pp.168-176.

Fiol, C.M., \& Lyles, M.A. (1985). Organizational learning. Academy of Management Review, 10(4), 803-813.

Fu, Y. \& Zhang, X. (2017) Trajectory of urban sustainability concepts: A 35-year bibliometric analyzis. Cities, 60, pp. 113-123.

Garcez, M. R., Rohden, A. B., \& de Godoy, L. G. G. (2018). The role of concrete compressive strength on the service life and life cycle of a RC structure: Case study. Journal of Cleaner Production, 172, 27-38.

Giest, S. (2017). Big data analytics for mitigating carbon emissions in smart cities: opportunities and challenges. European Planning Studies, 25(6), 941-957.

Gil-Garcia, J. R., Helbig, N., \& Ojo, A. (2014). Being smart: Emerging technologies and innovation in the public sector. Government Information Quarterly, 31, I1-I8. 
Gold, A.H., Malhotra, A. and Segars, A.H. (2001). Knowledge management: An organizational capabilities perspective. Journal of Management Information Systems, 18(1), pp.185-214.

Grimaldi, D., \& Fernandez, V. (2017). The alignment of University curricula with the building of a Smart City: A case study from Barcelona. Technological Forecasting and Social Change, 123, 298-306.

Hansen, M. T. (2002). Knowledge networks: explaining effective knowledge sharing in multiunit companies. Organization Science, 13: 232-248.

Harrison, C., Eckman, B., Hamilton, R., Hartswick, P., Kalagnanam, J., Paraszczak, J., \& Williams, P. (2010). Foundations for smarter cities. IBM Journal of Research and Development, 54(4), 1-16.

Hashem, I. A. T., Chang, V., Anuar, N. B., Adewole, K., Yaqoob, I., Gani, A., Ahmed, E., \& Chiroma, H. (2016). The role of big data in smart city. International Journal of Information Management, 36(5), 748-758.

Hens, L., Block, C., Cabello-Eras, J. J., Sagastume-Gutierez, A., Garcia-Lorenzo, D., Chamorro, C., Herrera Mendoza, K., Haeseldonckx, D., \& Vandecasteele, C. (2018). On the evolution of "Cleaner Production" as a concept and a practice. Journal of Cleaner Production, 172, 3323-3333.

Hepworth, M. E. (1990). Planning for the information city: the challenge and response. Urban Studies, 27(4), 537-558.

Hildebrandt, B., Hanelt, A., \& Firk, S. (2018). Sharing Yet Caring. Business \& Information Systems Engineering, 60(3), 227-241.

Ho, E. (2017). Smart subjects for a Smart Nation? Governing (smart) mentalities in Singapore. Urban Studies, 54(13), 3101-3118.

Holste, J.S. and Fields, D. (2010) Trust and tacit knowledge sharing and use. Journal of Knowledge Management, 14 (1), pp. 128-140.

Hosseini, S., Frank, L., Fridgen, G., \& Heger, S. (2018). Do Not Forget About Smart Towns. Business \& Information Systems Engineering, 60(3), 243-257.

Hughes, L., Dwivedi, Y.K., Misra, S.K., Rana, N.P., Raghavan, V., \& Akella, V. (2019). Blockchain research, practice and policy: Applications, benefits, limitations, emerging research themes and research agenda. International Journal of Information Management, 49, 114-129.

Hunter, G., Vettorato, D., \& Sagoe, G. (2018). Creating Smart Energy Cities for Sustainability through Project Implementation: A Case Study of Bolzano, Italy. Sustainability, 10(7), p.2167.

Huston, S., Rahimzad, R., \& Parsa, A. (2015). 'Smart'sustainable urban regeneration: Institutions, quality and financial innovation. Cities, 48, 66-75.

Ismagilova, E., Hughes, L., Dwivedi, Y. K., \& Raman, K. R. (2019). Smart cities: Advances in research-An information systems perspective. International Journal of Information Management, 47, 88-100.

Iveroth, S. P., Johansson, S., \& Brandt, N. (2013). The potential of the infrastructural system of Hammarby Sjöstad in Stockholm, Sweden. Energy Policy, 59, 716-726.

Jackson, S. E., Chuang, C. H., Harden, E. E., Jiang, Y., \& Joseph, J. M. (2006). Toward developing human resource management systems for knowledge-intensive teamwork", in Joseph, J. M. (Ed.), Research in Personnel and Human Resources Management, JAI, Amsterdam, 25, 27-70. 
Jarvenpaa, S. L., \& Staples, D. S. (2000). The use of collaborative electronic media for information sharing: an exploratory study of determinants. The Journal of Strategic Information Systems, 9(2-3), 129-154.

Kaklauskas, A., Zavadskas, E.K., Radzeviciene, A., Ubarte, I., Podviezko, A., Podvezko, V., Kuzminske, A., Banaitis, A., Binkyte, A. and Bucinskas, V. (2018). Quality of city life multiple criteria analyzis. Cities, 72, pp.82-93.

Kankanhalli, A., Tan, B. C., \& Wei, K. K. (2005). Contributing knowledge to electronic knowledge repositories: an empirical investigation. MIS Quarterly, 113-143.

Keathley-Herring, H., Van Aken, E., Gonzalez-Aleu, F., Deschamps, F., Letens, G., \& Orlandini, P. C. (2016). Assessing the maturity of a research area: bibliometric review and proposed framework. Scientometrics, 109(2), 927-951.

Kummitha, R. K. R., \& Crutzen, N. (2019). Smart cities and the citizen-driven internet of things: A qualitative inquiry into an emerging smart city. Technological Forecasting and Social Change, 140, 44-53.

Kumar, H., Singh, M.K., Gupta, M.P., \& Madaan, J. (2018). Moving towards smart cities: Solutions that lead to the Smart City Transformation Framework. Technological Forecasting and Social Change.

Lamal, P.A. (1990). On the importance of replication. Journal of Social Behavior and Personality, 5(4), p.31.

Laurini, R. (2017). Geographic Knowledge Infrastructure: Applications to Territorial Intelligence and Smart Cities. London: ISTE Press Ltd.

Lebel, L., Garden, P., Banaticla, M.R.N., Lasco, R.D., Contreras, A., Mitra, A.P., Sharma, C., Nguyen, H.T., Ooi, G.L., \& Sari, A. (2007). Integrating carbon management into the development strategies of urbanizing regions in Asia. Journal of Industrial Ecology, 11(2), 61-81.

Lee, J. H., Hancock, M. G., \& Hu, M. C. (2014). Towards an effective framework for building smart cities: Lessons from Seoul and San Francisco. Technological Forecasting and Social Change, 89, 80-99.

Lee, J. S., \& Kim, J. W. (2016). South Korea's urban green energy strategies: Policy framework and local responses under the green growth. Cities, 54, 20-27.

Lee, J., \& Lee, H. (2014). Developing and validating a citizen-centric typology for smart city services. Government Information Quarterly, 31, S93-S105.

Lee, J. H., Phaal, R., \& Lee, S. H. (2013). An integrated service-device-technology roadmap for smart city development. Technological Forecasting and Social Change, 80(2), 286-306.

Leonard-Barton, D. (1995). Wellsprings of Knowledge. Boston, MA: Harvard Business School Press.

Lenhart, J., Bouteligier, S., Mol, A. P., \& Kern, K. (2014). Cities as learning organisations in climate policy: the case of Malmö. International Journal of Urban Sustainable Development, 6(1), 89-106.

Lu, Z., Southworth, F., Crittenden, J., \& Dunhum-Jones, E. (2015). Market potential for smart growth neighbourhoods in the USA: A latent class analyzis on heterogeneous preference and choice. Urban Studies, 52(16), 3001-3017.

Lugaric, L. and Krajcar, S. (2016) Transforming cities towards sustainable low-carbon energy systems using emergy synthesis for support in decision making. Energy Policy, 98, pp. 471-482. 
Lytras, M., \& Visvizi, A. (2018). Who Uses Smart City Services and What to Make of It: Toward Interdisciplinary Smart Cities Research. Sustainability, 10(6).

Macke, J., Casagrande, R.M., Sarate, J.A.R., \& Silva, K.A. (2018) Smart city and quality of life: Citizens' perception in a Brazilian case study. Journal of Cleaner Production, 182, pp. 717-726.

Manitiu, D. N., \& Pedrini, G. (2016). Urban smartness and sustainability in Europe. An ex ante assessment of environmental, social and cultural domains. European Planning Studies, 24(10), 1766-1787.

March, H. and Ribera-Fumaz, R. (2016). Smart contradictions: The politics of making Barcelona a Self-sufficient city. European Urban and Regional Studies, 23(4), pp.816-830.

Marsal-Llacuna, M. L., Colomer-Llinàs, J., \& Meléndez-Frigola, J. (2015). Lessons in urban monitoring taken from sustainable and livable cities to better address the Smart Cities initiative. Technological Forecasting and Social Change, 90, 611-622.

McLean, A., Bulkeley, H., \& Crang, M. (2016). Negotiating the urban smart grid: Sociotechnical experimentation in the city of Austin. Urban Studies, 53(15), 3246-3263.

Meijer, A. and Bolívar, M.P.R., (2016). Governing the smart city: a review of the literature on smart urban governance. International Review of Administrative Sciences, 82(2), pp.392408.

Mendoza, J. M. F., Sanyé-Mengual, E., Angrill, S., García-Lozano, R., Feijoo, G., Josa, A., ... \& Rieradevall, J. (2015). Development of urban solar infrastructure to support low-carbon mobility. Energy Policy, 85, 102-114.

Michelucci, F. V., \& De Marco, A. (2017). Smart communities inside local governments: a pie in the sky?. International Journal of Public Sector Management, 30(1), 2-14.

Min, W., Yu, L., Yu, L., \& He, S. (2018). People logistics in smart cities. Communications of the ACM, 61(11), 54-59.

Mizruchi, M. S., \& Marquis, C. (2006). Egocentric, sociocentric, or dyadic?: Identifying the appropriate level of analyzis in the study of organizational networks. Social Networks, 28(3), 187-208.

Monaghan, P., North, P., \& Southern, A. (2016). Ecological empowerment and Enterprise Zones: pain free transitions to sustainable production in cities or fool's gold?. Journal of Cleaner Production, 134, 395-405.

Morris, P. (2017). Climate change and what the project management profession should be doing about it - a UK perspective. Princes Risborough: Association for Project Management. Mosannenzadeh, F., Bisello, A., Diamantini, C., Stellin, G., \& Vettorato, D. (2017). A casebased learning methodology to predict barriers to implementation of smart and sustainable urban energy projects. Cities, 60, 28-36.

Mosannenzadeh, F., Bisello, A., Vaccaro, R., D'Alonzo, V., Hunter, G. W., \& Vettorato, D. (2017). Smart energy city development: A story told by urban planners. Cities, 64, 54-65.

Nam, T., \& Pardo, T. A. (2011, September). Smart city as urban innovation: Focusing on management, policy, and context. In Proceedings of the 5th International Conference on Theory and Practice of Electronic Governance (pp. 185-194). ACM.

Neirotti, P., De Marco, A., Cagliano, A. C., Mangano, G., \& Scorrano, F. (2014). Current trends in Smart City initiatives: Some stylised facts. Cities, 38, 25-36.

Nevens, F., Frantzeskaki, N., Gorissen, L., \& Loorbach, D. (2013). Urban Transition Labs: co-creating transformative action for sustainable cities. Journal of Cleaner Production, 50, 111-122. 
Newell, S. (2015). Managing knowledge and managing knowledge work: what we know and what the future holds. Journal of Information Technology, 30(1), 1-17.

Nonaka, I., \& Takeuchi, H. (1995). The Knowledge-Creating Company: How Japanese Companies Create the Dynamics of Innovation. New York: Oxford University Press.

Nyberg, R.A. (2018). Using 'smartness' to reorganise sectors: Energy infrastructure and information engagement. International Journal of Information Management, 39, 60-68.

Parks, D. (2019). Energy efficiency left behind? Policy assemblages in Sweden's most climate-smart city. European Planning Studies, 27(2), 318-335.

Paroutis, S., Bennett, M., \& Heracleous, L. (2014). A strategic view on smart city technology: The case of IBM Smarter Cities during a recession. Technological Forecasting and Social Change, 89, 262-272.

Pawlowsky, P. (2001). The treatment of organizational learning in management science. In M. Dierkes, A. B. Antal, J. Child, \& I. Nonaka (Eds.), Handbook of organizational learning and knowledge (pp. 61-88). Oxford, UK: Oxford University Press.

Pincetl, S., Chester, M., Circella, G., Fraser, A., Mini, C., Murphy, S., Reyna, J., \& Sivaraman, D. (2014). Enabling future sustainability transitions: an urban metabolism approach to Los Angeles. Journal of Industrial Ecology, 18(6), 871-882.

Privitera, R., Palermo, V., Martinico, F., Fichera, A., \& La Rosa, D. (2018). Towards lower carbon cities: urban morphology contribution in climate change adaptation strategies. European Planning Studies, 26(4), 812-837.

Ramaswami, A., Weible, C., Main, D., Heikkila, T., Siddiki, S., Duvall, A., Pattison, A., \& Bernard, M. (2012). A social-ecological-infrastructural systems framework for interdisciplinary study of sustainable city systems: An integrative curriculum across seven major disciplines. Journal of Industrial Ecology, 16(6), 801-813.

Reyna, J. L., \& Chester, M. V. (2015). The growth of urban building stock: Unintended lock-in and embedded environmental effects. Journal of Industrial Ecology, 19(4), 524-537. Romão, J., Kourtit, K., Neuts, B., \& Nijkamp, P. (2018). The smart city as a common place for tourists and residents: A structural analyzis of the determinants of urban attractiveness. Cities, 78, 67-75.

Ruhlandt, R.W.S. (2018). The governance of smart cities: A systematic literature review. Cities, 81, 1-23.

Schiller, F. (2016). Urban transitions: scaling complex cities down to human size. Journal of Cleaner Production, 112, 4273-4282.

Schneider Electric (2014). Urban Mobility in the Smart City Age. London: Schneider Electric.

Shin, D.H. (2014). A socio-technical framework for Internet-of-Things design: A humancentered design for the Internet of Things. Telematics and Informatics, 31(4), pp. 519-531.

Shin, D.H. and Jin Park, Y. (2017). Understanding the Internet of Things ecosystem: multilevel analyzis of users, society, and ecology. Digital Policy, Regulation and Governance, 19(1), pp.77-100.

Simon, D. (2013). Climate and environmental change and the potential for greening African cities. Local Economy, 28(2), 203-217.

Staffans, A. and Horelli, L. (2014). Expanded urban planning as a vehicle for understanding and shaping smart, liveable cities. The Journal of Community Informatics, 10(3). 
Stern, N., Peters, S., Bakhshi, V., Bowen, A., Cameron, C., Catovsky, S., Crane, D., Cruickshank, S., Dietz, S. and Edmonson, N. (2006). Stern Review: The economics of climate change. London: HM Treasury.

Stocchero, A., Seadon, J. K., Falshaw, R., \& Edwards, M. (2017). Urban Equilibrium for sustainable cities and the contribution of timber buildings to balance urban carbon emissions: A New Zealand case study. Journal of cleaner production, 143, 1001-1010.

Tamilmani, K., Rana, N.P., Prakasam, N., \& Dwivedi, Y.K., 2019. The battle of Brain vs. Heart: A literature review and meta-analyzis of "hedonic motivation" use in UTAUT2. International Journal of Information Management, 46, 222-235.

Tao, Y., Li, F., Crittenden, J. C., Lu, Z., \& Sun, X. (2016). Environmental impacts of China's urbanization from 2000 to 2010 and management implications. Environmental management, 57(2), 498-507.

Taylor Buck, N., \& While, A. (2017). Competitive urbanizm and the limits to smart city innovation: The UK Future Cities initiative. Urban Studies, 54(2), 501-519.

Theodoridou, I., Papadopoulos, A. M., \& Hegger, M. (2012). A feasibility evaluation tool for sustainable cities-A case study for Greece. Energy Policy, 44, 207-216.

UN Habitat (2011). Cities and climate change: Global report on human settlements 2011. London: Earthscan.

Valdez, A. M., Cook, M., Langendahl, P. A., Roby, H., \& Potter, S. (2018). Prototyping sustainable mobility practices: user-generated data in the smart city. Technology Analyzis \& Strategic Management, 30(2), 144-157.

van Winden, W., \& van den Buuse, D. (2017) Smart city pilot projects: Exploring the dimensions and conditions of scaling up. Journal of Urban Technology, 24 (4), pp. 51-72.

Van Zoonen, L. (2016). Privacy concerns in smart cities. Government Information Quarterly, 33(3), 472-480.

Visvizi, A., \& Lytras, M.D. (2018). Rescaling and refocusing smart cities research: from mega cities to smart villages. Journal of Science and Technology Policy Management, 9(2), 134-145.

Visvizi, A., Lytras, M.D., Damiani, E. \& Mathkour, H. (2018). Policy making for smart cities: Innovation and social inclusive economic growth for sustainability. Journal of Science and Technology Policy Management, 9(2), pp.126-133.

Viitanen, J., \& Kingston, R. (2014). Smart cities and green growth: outsourcing democratic and environmental resilience to the global technology sector. Environment and Planning A, 46(4), 803-819.

Wasko, M. M., \& Faraj, S. (2005). Why should I share? Examining social capital and knowledge contribution in electronic networks of practice. MIS Quarterly, 35-57.

Webb, J., Hawkey, D., \& Tingey, M. (2016). Governing cities for sustainable energy: The UK case. Cities, 54, 28-35.

White, J. M. (2016). Anticipatory logics of the smart city's global imaginary. Urban Geography, 37(4), 572-589.

Williams, M.D., Dwivedi, Y.K., Lal, B. \& Schwarz, A. (2009). Contemporary trends and issues in IT adoption and diffusion research. Journal of Information Technology, 24(1), pp.110.

Yeh, H. (2017). The effects of successful ICT-based smart city services: From citizens' perspectives. Government Information Quarterly, 34(3), 556-565. 
Yigitcanlar, T., Velibeyoglu, K., \& Martinez-Fernandez, C. (2008). Rising knowledge cities: the role of urban knowledge precincts. Journal of Knowledge Management, 12(5), 8-20.

Ylipulli, J., Suopajärvi, T., Ojala, T., Kostakos, V., \& Kukka, H. (2014). Municipal WiFi and interactive displays: Appropriation of new technologies in public urban spaces. Technological Forecasting and Social Change, 89, 145-160.

Zawieska, J., \& Pieriegud, J. (2018). Smart city as a tool for sustainable mobility and transport decarbonisation. Transport Policy, 63, 39-50.

Zhang, X., Hes, D., Wu, Y., Hafkamp, W., Lu, W., Bayulken, B., Schnitzer, H., \& Li, F. (2016). Catalyzing sustainable urban transformations towards smarter, healthier cities through urban ecological infrastructure, regenerative development, eco towns and regional prosperity. Journal of Cleaner Production.

Zygiaris, S. (2012). Smart city reference model: Assisting planners to conceptualize the building of smart city innovation ecosystems. Journal of the Knowledge Economy, $4(2), 217-231$. 
Appendix - table A: classification of empirical articles

\begin{tabular}{|c|c|c|c|c|}
\hline Citation & Stakeholder Interaction type & Methodology & Themes & Country/Context \\
\hline Affolderbach and Schulz (2017) & Egocentric & Mixed methods & Enablers & Italy \\
\hline Andersson (2016) & Egocentric & Mixed methods & Strategy & Sweden \\
\hline Axelsson and Granath (2018) & Egocentric & Qualitative & Citizens & Sweden \\
\hline Bazán et al., (2018) & Clique & Mixed methods & Benefits & UK \\
\hline Behrendt (2016) & Egocentric & Mixed methods & Citizens & UK \\
\hline Belanche-Gracia et al., (2015) & Egocentric & Quantitative & Enablers & Spain \\
\hline Bennett and Newborough (2001) & Clique & Qualitative & Strategy & UK \\
\hline Bifulco et al., (2016) & Clique & Qualitative & Enablers & Multiple European cities \\
\hline Bresciani et al., (2018) & Clique & Quantitative & Enablers & Italy \\
\hline Buch et al., (2018) & Egocentric & Mixed methods & Citizens & $\mathrm{UK}$ \\
\hline Burchell et al., (2016) & Sociocentric & Quantitative & Citizens & UK \\
\hline Caponio et al., (2015) & Clique & Quantitative & Frameworks & Italy \\
\hline Caprotti (2014) & Egocentric & Qualitative & Frameworks & UK \\
\hline Caprotti et al., (2015) & Sociocentric & Qualitative & Strategy & UK and Netherlands \\
\hline Carè et al., (2018) & Sociocentric & Qualitative & Enablers & Italy \\
\hline Chatterjee et al., (2018) & Clique & Quantitative & Benefits & India \\
\hline Chong et al., (2018) & Egocentric & Quantitative & Enablers & US \\
\hline Cledou et al (2018) & Clique & Qualitative & Frameworks & Multiple \\
\hline Coaffee (2008) & Clique & Qualitative & Enablers & UK \\
\hline Cugurullo (2016) & Clique & Qualitative & Strategy & UK \\
\hline Cugurullo (2018) & Clique & Qualitative & Strategy & Spain \\
\hline De Jong et al., (2013) & Clique & Mixed methods & Enablers & UK \\
\hline De Jong et al., (2015) & Clique & Qualitative & Frameworks & Sweden \\
\hline De Luca G et al., (2018) & Egocentric & Qualitative & Enablers & Brazil \\
\hline Deakin and Reid (2018) & Clique & Mixed methods & Strategy & Poland \\
\hline Fu and Zhang (2017) & Sociocentric & Qualitative & Frameworks & Italy \\
\hline Garcez et al., (2018) & Egocentric & Qualitative & Strategy & Belgium \\
\hline
\end{tabular}




\section{Giest (2017)}

Gil-Garcia et al., (2014)

Grimaldi et al., (2017)

Hens et al., (2018)

Hepworth (1990)

Hildebrandt et al., (2018)

Ho (2017)

Hosseini et al., (2018)

Huston et al., (2015)

Iveroth et al., (2013)

Kaklauskas et al., (2018)

Kummitha and Crutzen, N. (2019)

Lebel et al., (2007)

Lee and Lee (2014)

Lee et al., (2013)

Lee et al., (2014)

Lee and Kim (2016)

Lenhart et al., (2014)

Lohrey and Creutzig (2016)

Lu et al., (2015)

Lugaric and Krajcar (2016)

Macke et al., (2018)

Manitiu and Pedrini (2016)

March and Ribera-Fumaz (2016)

Marsal-Llacuna et al., (2015)

McLean et al., (2016)

Mendoza et al., (2015)

Michelucci and De Marco (2017)

Min (2018)

Monaghan et al., (2016)
Clique

Clique

Egocentric

Sociocentric

Clique

Clique

Egocentric

Sociocentric

Sociocentric

Egocentric

Sociocentric

Egocentric

Clique

Egocentric

Sociocentric

Clique

Clique

Egocentric

Sociocentric

Clique

Egocentric

Egocentric

Sociocentric

Egocentric

Clique

Egocentric

Egocentric

Clique

Sociocentric

Clique

$\begin{array}{lll}\text { Qualitative } & \text { Strategy } & \text { Multiple European } \\ \text { Qualitative } & \text { Strategy } & \text { Not mentioned } \\ \text { Qualitative } & \text { Enablers } & \text { Spain } \\ \text { Mixed methods } & \text { Enablers } & \text { Lithuania } \\ \text { Qualitative } & \text { Strategy } & \text { UK } \\ \text { Quantitative } & \text { Benefits } & \text { Germany } \\ \text { Qualitative } & \text { Strategy } & \text { Singapore } \\ \text { Qualitative } & \text { Strategy } & \text { Germany } \\ \text { Qualitative } & \text { Frameworks } & \text { US } \\ \text { Mixed methods } & \text { Frameworks } & \text { China } \\ \text { Qualitative } & \text { Frameworks } & \text { Hong Kong } \\ \text { Qualitative } & \text { Frameworks } & \text { India } \\ \text { Qualitative } & \text { Benefits } & \text { Regions in Asia } \\ \text { Qualitative } & \text { Citizens } & \text { South Korea } \\ \text { Qualitative } & \text { Frameworks } & \text { S.Korea } \\ \text { Qualitative } & \text { Frameworks } & \text { US and S.Korea } \\ \text { Mixed methods } & \text { Strategy } & \text { South Korea } \\ \text { Qualitative } & \text { Strategy } & \text { China } \\ \text { Quantitative } & \text { Benefits } & \text { Undefined } \\ \text { Quantitative } & \text { Frameworks } & \text { US } \\ \text { Qualitative } & \text { Frameworks } & \text { Croatia } \\ \text { Mixed methods } & \text { Citizens } & \text { Peru } \\ \text { Quantitative } & \text { Frameworks } & \text { Europe } \\ \text { Qualitative } & \text { Strategy } & \text { UK } \\ \text { Quantitative } & \text { Enablers } & \text { Spain } \\ \text { Qualitative } & \text { Strategy } & \text { US } \\ \text { Mixed methods } & \text { Benefits } & \text { Spain } \\ \text { Qualitative } & \text { Strategy } & \text { Italy } \\ \text { Qualitative } & \text { Citizens } & \text { China } \\ \text { Qualitative } & \text { Frameworks } & \text { Croatia } \\ & & \\ \text { Ming } & & \end{array}$




$\begin{array}{lllll}\text { Mosannenzadeh et al., (2017a) } & \text { Clique } & \text { Qualitative } & \text { Enablers } & \text { China } \\ \text { Mosannenzadeh et al., (2017b) } & \text { Clique } & \text { Mixed methods } & \text { Enablers } & \text { Italy } \\ \text { Nevens et al., (2013) } & \text { Clique } & \text { Mixed methods } & \text { Strategy } & \text { Sweden } \\ \text { Parks (2019) } & \text { Egocentric } & \text { Qualitative } & \text { Strategy } & \text { Sweden } \\ \text { Paroutis et al., (2014) } & \text { Egocentric } & \text { Qualitative } & \text { Strategy } & \text { China } \\ \text { Pincetl et al., (2014) } & \text { Egocentric } & \text { Mixed methods } & \text { Frameworks } & \text { US } \\ \text { Privitera et al., (2018) } & \text { Egocentric } & \text { Qualitative } & \text { Frameworks } & \text { Italy } \\ \text { Ramaswami et al., (2012) } & \text { Sociocentric } & \text { Qualitative } & \text { Frameworks } & \text { Undefined } \\ \text { Reyna and Chester (2015) } & \text { Egocentric } & \text { Quantitative } & \text { Frameworks } & \text { Italy } \\ \text { Romão et al.,(2018) } & \text { Sociocentric } & \text { Mixed methods } & \text { Benefits } & \text { UK } \\ \text { Schiller (2016) } & \text { Egocentric } & \text { Quantitative } & \text { Strategy } & \text { China } \\ \text { Simon (2013) } & \text { Clique } & \text { Quantitative } & \text { Enablers } & \text { Belgium } \\ \text { Stocchero et al., (2017) } & \text { Egocentric } & \text { Mixed methods } & \text { Benefits } & \text { Italy } \\ \text { Tao et al., (2016) } & \text { Clique } & \text { Quantitative } & \text { Frameworks } & \text { South Korea } \\ \text { Taylor Buck and While (2017) } & \text { Egocentric } & \text { Qualitative } & \text { Enablers } & \text { UK } \\ \text { Theodoridou et al., (2012) } & \text { Egocentric } & \text { Qualitative } & \text { Enablers } & \text { US } \\ \text { Valdez et al., (2018) } & \text { Sociocentric } & \text { Qualitative } & \text { Benefits } & \text { UK } \\ \text { Van Zoonen (2016) } & \text { Egocentric } & \text { Qualitative } & \text { Enablers } & \text { Netherlands } \\ \text { Vitanen and Kingston (2014) } & \text { Clique } & \text { Mixed methods } & \text { Strategy } & \text { US } \\ \text { Webb et al., (2016) } & \text { Sociocentric } & \text { Qualitative } & \text { Enablers } & \text { Ireland } \\ \text { White (2016) } & \text { Clique } & \text { Qualitative } & \text { Strategy } & \text { China } \\ \text { Yeh (2017) } & \text { Egocentric } & \text { Quantitative } & \text { Enablers } & \text { Taiwan } \\ \text { Ylipulli et al., (2014) } & \text { Sociocentric } & \text { Mixed methods } & \text { Enablers } & \text { Finland } \\ \text { Zawieska and Pieriegud (2018) } & \text { Clique } & \text { Qualitative } & \text { Enablers } & \text { Brazil } \\ \text { Zhang et al., (2016) } & \text { Clique } & \text { Qualitative } & \text { Strategy } & \text { UAE } \\ & & & & \end{array}$

